\title{
DETEKSI DINI DAN EDUKASI KESEHATAN PADA JEMAAT IHOP MANGGA BESAR JAKARTA
}

\author{
Belet Lydia Ingrit', Marisa Manik², Veronica Paula ${ }^{3}$, Fransiska Ompusunggu ${ }^{4}$, \\ Tirolyn Panjaitan 5 \\ 1,2,3,4,5Fakultas Keperawatan - Universitas Pelita Harapan
}

$\underline{\text { Belet.ingrit@uph.edu }}^{1}, \underline{\text { marisa.manik@uph.edu }}^{2}$, veronica.paula@uh.edu $^{3}, \underline{\text { fransiska.ompusunggu@uph.edu }}^{4}$, tirolyn.panaitan@uph.edu ${ }^{5}$

\begin{abstract}
Abstrak
Jemaat gereja IHOP Mangga Besar adalah salah satu komunitas yang terletak di pusat kota dengan karakteristik jemaat yang terdiri dari lansia, dewasa muda dan remaja. Karakteristik jemaat yang beraneka ragam dengan kondisi ekonomi dan tingkat pendidikan yang rendah adalah salah satu kendala dalam meningkatkan status kesehatan mereka. Tujuan kegiatan ini adalah untuk mengetahui status kesehatan jemaat IHOP Mangga Besar. Metode pelaksanaan kegiatan ini adalah dengan melakukan pemeriksaan kesehatan secara umum yaitu mengecek tekanan darah, tinggi badan, cek kadar gula dalam darah, kolesterol dan asam urat serta edukasi dan pengobatan gratis. Hasil didapatkan jumlah jemaat yang hadir sebanyak 91 orang (52,7\% perempuan dan 47,3\% laki-laki) dengan kisaran usia 20 - 75 tahun. Masalah kesehatan yang terjadi adalah pre hipertensi sebanyak 24.2\% (22 orang) dan hipertensi 19.8\% (18 orang), underweight 8.7\% (8 orang) dan overeweight 30.9\% (28 orang), kolesterol tinggi sebanyak 14.3\% (13 orang), asam urat tinggi 24.2\% (22 orang) dan kadar gula darah darah yang tinggi sebanyak 5.4\% (5 orang). Kesimpulan yang didapatkan sebagian dari jemaat IHOP memiliki status kesehatan yang rendah dan butuh untuk pemeriksaan lebih lanjut (berkelanjutan).
\end{abstract}

Kata kunci: Deteksi dini, Edukasi kesehatan, Jemaat IHOP

\section{PENDAHULUAN}

Indonesia House of Praise (IHOP) Mangga Besar adalah tempat ibadah atau rumah pujian yang didirikan sejak tahun 2006 oleh beberapa anak anak Tuhan yang bekerja dan mau meluangkan waktunya untuk melayani di hari Sabtu. Pelayanan yang diberikan oleh IHOP adalah kegiatan ibadah dan pemberian makanan dan minuman. Jemaat yang hadir di pelayanan tersebut adalah orangtua, anakanak mudan dan anak anak jalanan yang sebagian dari mereka tidak memiliki rumah/tempat tinggal. Aktivitas atau kegiatan dari jemaat IHOP sebagian adalah anak jalanan dan tidak bekerja. Jumlah jemaat yang aktif berkisar 75 orang namun jika semua jemaat bisa hadir 100 orang.

Latar belakang jemaat yang hadir sebagai besar melakukan kegiatannya di luar rumah karena memang sebagian dari mereka bekerja tidak menentu (pengamen, anak jalanan) dan tidak memiliki tempat tinggal yang tetap. Latar belakang tingkat pendidikan yang rendah serta keadaan ekonomi yang kurang menjadu salah satu hambatan bagi jemaat untuk dapat meningkatkan status kesehatannya. Belum pernah dilakukan kegiatan pelayanan kepada mereka terkait dengan kesehatan seperti deteksi dini atau edukasi kesehatan.

Kesehatan yang dimaksud dalam UU No.36 tahun 2009 adalah "Keadaan sehat baik secara sehat secara fisik, mental, spiritual, maupun sosial". Berdasarkan profil yang didapatkan dari salah satu mitra Gereja IHOP Mangga Besar, belum ada satupun kegiatan ataupun edukasi kesehatan yang pernah dilakukan di wilayah tersebut. Sehingga perlu untuk dilakukan kegiatan edukasi sebagai

$$
\text { Kesehatan } 402
$$


upaya dalam meningkatkan status kesehatan seseorang karena jemaat IHOP Mangga Besar sebagai salah satu sumber daya manusia yang perlu ditingkatkan status kesehatannya.

Sumber daya manusia adalah bagian krusial dalam pembangunan suatu bangsa dan kualitas kesehatan sangat dipengaruhi oleh latarbelakang pendidikan, gizi, lingkungan hidup dan kemampuan ekonomi. Kesehatan merupakan faktor pertama dan utama dalam mempengaruhi kualitas Sumber Daya Manusia dalam mendukung pembangunan berkelanjutan. Kondisi kesehatan masyarakat dapat dilihat berdasarkan pencapaian umur angka harapan hidup, angka kesakitan (morbiditas), angka kecacatan, angka kematian (mortalitas), pencapaian keikutsertaan dalam pelayanan eksehatan, pencapaian kepuasan internal, kepuasan eksternal, partisipasi dalam kehidupan sosial dan lingkungan (Hapsari, D., Sari P \& Pradono, J. (2009).

Kegiatan PkM ini adalah untuk dapat memaksimalkan status kesehatan dan meningkatkan pengetahuan mereka tentang status kesehatan mereka masing-masing. Rencana penanganan masalah terkait kondisi kesehatan jemaat IHOP Mangga Besar adalah dengan melakukan kegiatan pemeriksaan keseahatan dan edukasi. Kegiatan yang diperlukan adalah deteksi dini dengan melakukan pengecekan gula darah, kolesterol, asam urat, pengukuran tekanan darah, berat badan dan tinggi badan dan dilanjutkan dengan edukasi kesehatan.

\section{METODE}

Kegiatan ini dilaksanakan dalam satu hari yang terdiri dari pemeriksaan fisik, pemberian obat gratis dan pemberian edukasi per individu. Jumlah peserta yang terdaftar mengisi daftar hadir ada 91 orang. Kegiatan yang dimulai dari jam 08.00 WIB namun jam 07.30 sudah banyak peserta yang sudah menunggu di bagian pendaftaran. Peserta sangat antusias dengan kegiatan yang dilakukan, mulai dari remaja, dewasa akhir dan lansia mengikuti kegiatan ini.

Target peserta kegiatan Pengabdian kepada Masyarakat (PkM) adalah seluruh jemaat IHOP Mangga Besar terdiri dari para lansia, orangtua, remaja dan anak-anak dengan total 100 peserta dengan lokasi kegiatan di Gereja Indonesia House of Praise (IHOP) Mangga Besar, Jl. Mangga Besar Raya No 77 Jakarta Barat. Waktu pelaksaan Sabtu, 24 November 2018, pada pukul 08.00 hingga pukul 13.00 WIB.

Metode pelaksanaan kegiatan terdiri dari tiga bagian yaitu : 1) Pemeriksaan kesehatan yaitu tim PkM melakukan pemeriksaan kesehatan dengan melakukan pemeriksaan secara umum yaitu pengukuran tinggi badan, penimbangan berat badan, pengecekan tekanan darah, kolesterol, asam urat dan kadar gula dalam. Kegiatan ini dilaksanakan oleh anggota tim kesehatan yaitu perawat , 2) Pemberian pengobatan, yaitu pemberian obatobatan oleh tim medis (dokter) berdasarkan hasil pemeriksaan kesehatan yang tidak normal yaitu obat untuk hiperglukosa, hipertensi, hiperkolesterol, asam urat dan pemberian vitamin. Beberapa peserta banyak yang melakukan konsultasi kesehatan terkait dengan hasil pemeriksaan mereka 3) Edukasi yaitu setelah hasil pemeriksaan fisik didapatkan dan pengukuran dilakukan, hasil yang tidak normal, seperti hipertensi, kadar gula darah tinggi, asam urat dan cek kolesterol dalam batas tidak normal, maka tim kesehatan baik dokter maupun perawat memberikan edukasi terkait dengan masalah kesehatan yang dialami

\section{HASIL DAN PEMBAHASAN}

\section{Hasil}

Kegiatan pemeriksaan kesehatan diikuti oleh lansia, dewasa, dan remaja dengan jumlah peserta yang hadir 91 orang dengan rentang usia peserta pemeriksaan kesehatan 20 - 75 tahun. Semua peserta yang hadir sangat antusias untuk dilakukan pemeriksaan kesehatan, bahkan beberapa peserta sudah hadir lebih awal sebelum kegiatan dimulai. Pada laporan PkM ini rentang usia dibagi berdasarkan usia lansia $(\geq$ 60 tahun) dan usia produktif (15-59 tahun). Hasil dari kegiatan ini ada dalam tabel di bawah ini :

Tabel 1 Distribusi demografik peserta

\begin{tabular}{rr}
\hline Kategori & Jumlah \\
\hline Kesehatan & 403
\end{tabular}


(n) $\quad(\%)$

Jenis kelamin

$\begin{array}{lll}\text { Perempuan } & 48 & 52.7 \\ \text { Laki-laki } & 43 & 47.3\end{array}$

Usia

Lansia

$37 \quad 40.6$

( $\geq 60$ tahun)

Produktif $\quad 54 \quad 59.4$

(15-59 tahun)

Pada tabel 1 yaitu tabel distribusi demografik peserta dapat dilihat bahwa jumlah peserta perempuan lebih banyak (52.7\%) dibandingkan peserta laki-laki (47.3\%) sedangkan berdasarkan distribusi usia, kelompok usia produktif jumlahnya masih lebih banyak (59.4\%) dibandingkan dengan peserta yang lansia $(40.6 \%)$. Hasil pengukuran kesehatan peserta dapat dilihat pada tabel 2 dibawah ini :

Tabel 2 Distribusi peserta berdasarkan hasil pengukuran kesehatan

\begin{tabular}{lcc}
\hline Variabel & $\begin{array}{l}\text { Jumlah } \\
(\mathrm{n})\end{array}$ & $\begin{array}{l}\text { Presentase } \\
(\%)\end{array}$ \\
\hline Tekanan darah (mmHg) & & \\
Normal & 51 & 56 \\
Prehipertensi & 22 & 24,2 \\
\hline Hipertensi & 18 & 19,8 \\
& & \\
Indeks Massa Tubuh (kg/m2) & & 8,7 \\
Underweight (<18,5) & 8 & 60,4 \\
Normal (18,5-25) & 55 & 30,9 \\
Overweight (>25) & 28 & \\
& & \\
Kadar Kolesterol (mg/dl) & 14 & 15.4 \\
Normal (<200) & 13 & 14.3 \\
Meningkat $(\geq 200)$ & 64 & \\
Tidak terkaji & & \\
Kadar Gula darah sewaktu & & \\
\hline
\end{tabular}

$(\mathrm{mg} / \mathrm{dl})$

Normal $(<200)$

Meningkat $(\geq 200)$

$45 \quad 49.4$

$5 \quad 5.4$

Tidak terkaji

Kadar asam urat (mg/dl) $\quad 38 \quad 41.7$

Laki-laki 3.4-7 $22 \quad 24.2$

Perempuan 2.4-6 $\quad 31 \quad 34.1$

Meningkat $\geq 6$-7

Tidak terkaji

Berdasarkan tabel 2 didapatkan hasil bahwa $56 \%$ peserta (51 orang) memiliki tekanan darah normal baik sistolik maupun diastolic dan gejala prehipertensi sebanyak $24.2 \%$ (22 orang) dan gejala hipertensi sebanyak $19.8 \% 18$ orang). Pada hasil pengukuran IMT, sebagian besar peserta yaitu $60.4 \%$ (55 orang) memiliki IMT yang normal dan overweight sebanyak $30.9 \%$ (28 orang) sedangkan untuk underweight hanya sebesar $8.7 \%$ (8 orang). Kadar kolesterol dari hasil didapatkan memiliki nilai normal hanya $15.4 \%$ (14 orang) dan meningkat sebanyak $14.3 \% .(13$ orang), dan ada lebih dari setengah peserta yaitu $70.3 \%$ (64 orang) tidak terkaji karena ketersediaan stok alat ukur, sedangkan untuk kadar gula darah sewaktu dengan nilai normal sebesar $49.4 \%$ (45 orang), meningkat hanya 5.4\% (5 orang) dan yang tidak terkaji hampir dari setengah jumlah peserta yang hadir yaitu $45.2 \%$ (41 orang). Pada pemeriksaan kadar asam urat didapatkan hasil untuk hasil asam urat yang normal hampir setengah dari jumlah peserta yang hadir yaitu $41.7 \%$ (38 orang) dan yang meningkat sebanyak $24.2 \%$ sedangkan yang tidak tidak terkaji ada $34.1 \%$ (31 orang) dikarenakan ketersediaan stok alat ukur.

\section{Pembahasan}

Berdasarkan hasil dari pemerksaan kesehatan pada jemaat Indonesia House of Praise (IHOP), didapatkan hasil bahwa status kesehatan jemaat IHOP masih perlu ditingkatkan. Pada bagian pemeriksaan tekanan darah, 44\% (40 peserta) yang mengalami tekanan darah tidak normal yaitu pre hipertensi dan hipertensi. Menurut Kemenkes RI (2014), hipertensi masih menjadi tantangan terbesar 
di Indonesia. angka ini tercatat di pelayanan kesehatan primer di Puskemasmas selain itu tekanan darah tinggi adalah salah satu penyakit tidak menular (PTM) yang meliputi penyakit degeneratif dan man made desease atau penyakit yang disebabkan oleh manusia itu sendiri yang merupakan faktor utama masalah morbiditas yaitu angka kesakitan dan mortalitas (angka kematian). Hal ini sejalan dengan Rahajeng \& Tuminah (2009), yang mengatakan bahwa faktor risiko hipertensi di Indonesia adalah umur, pria, tingkat pendidikan rendah, kebiasaan merokok, konsumsi kopi/teh lebih dari satu kali per hari, alkohol, jarang berolahraga atau aktivitas fisik, dan obesitas. Selain itu Rahajeng \& Tuminah, (2009) mengatakan bahwa prevalensi hipertensi di Indonesia sebesar $32,2 \%$, sedangkan prevalensi hipertensi berdasarkan diagnosis oleh tenaga kesehatan dan atau riwayat minum obat hanya $7,8 \%$ atau hanya $24,2 \%$ dari kasus hipertensi di masyarakat. Oleh karena itu perlunya program pencegahan hipertensi yang dimulai dari pengendalian obesitas yaitu mengatur pola makan keluarga, melakukan gerakan peningkatan aktivitas fisik (olahraga) dan berhenti merokok.

Penyakit hipertensi salah satu masalah kesehatan yang paling sering ditemukan di dalam masyarakat dan mengakibatkan angka kesakitan (morbiditas) yang tinggi. Hipertensi merupakan salah satu Penyakit Tidak Menular (PTM) yang menjadi masalah kesehatan yang sangat serius saat ini atau dikenal dengan istilah the silent killer. Sehingga dapat dsimpulkan bahwa penyakit hipertensi tidak bisa kita anggap remeh dan harus segera diatasi.

Penyebab pemicu terjadinya hipertensi, adalah salah satunya adalah obesitas. Tekanan darah tinggi yang disertai dengan keadaan obesitas dapat disebabka oleh berbagai faktor yaitu usia, jenis kelamin, dan suku budaya tertentu di Indonesia. Namun Julianti, Pangastuti \& Ulvie (2017) menyatakan bahwa "Tidak terdapat hubungan yang signifikan antara obesitas dengan tekanan darah tinggi". Namun jika dihubungkan dengan jenis kelamin, hipertensi lebih banyak dialami oleh perempuan, hal ditegaskan oleh adanya penelitian Kusumawaty, Hidayat \& Ginanjar (2016) pada lansia di wilayah Ciamis.
Oleh karena itu perlunya deteksi dini kasus hipertensi di masyarakat salah satunya dengan diadakannya kegiatan seperti pengabdian kepada masyarakat dan peningkatan sarana atau fasilitas pengobatan hipertensi di Puskesmas dapat dilakukan dalam rangka menurunkan angka kejadian hipertensi. Selain itu kompetensi tenaga kesehatan (dokter dan perawat) dalam tatalaksana kasus hipertensi juga perlu untuk ditingkatkan.

Pada hasil pemeriksaan kesehatan di jemaat Indonesia House of Praise (IHOP) Mangga Besar Jakarta, sebagian besar hasil IMT berada pada hasil normal yaitu $60,4 \%$ (55 peserta), namun untuk hasil overweight masih menduduki peringkat ke dua yaitu sebanyak 30,9\%. Hal ini jika tidak segera diatasi dapat menjadi faktor risiko untuk terjadinya hipertensi. Penelitian yang dilakukan oleh Sulastri, Elmatris \& Ramadhani (2012) mengatakan bahwa "Terdapat hubungan yang signifikan antara obesitas dan kejadian hipertensi". Berdasarkan penelitian di Indonesia, angka kejadian obesitas pada perempuan dewasa usia 19-55 tahun sebesar 29.4\% (Diana, Yuliana, Yasmin \& hardinsyah, 2013). Prevalensi kegemukan (obesitas) cenderung meningkat sesuai dengan pertambahan usia, dan akan mencapai puncaknya pada masa usia dewasa. Hasil Riskesdas (2010) menunjukkan bahwa " $21.7 \%$ orang dewasa Indonesia mengalami kegemukan (termasuk obesitas), dan perempuan memiliki prevalensi yang lebih tinggi (26.9\%) dibandingkan laki-laki (16.3\%)".

Diana, Yuliana, Yasmin \& hardinsyah (2013) menyatakan bahwa perempuan yang berstatus menikah, berpendapatan tinggi, tinggal di dalam perkotaan, melakukan aktivitas fisik ringan, mengonsumsi makanan dan minuman manis lebih dari 10\% Angka Kecukupan Energi (AKE), mengonsumsi karbohidrat lebih dari 55\% AKE, serta berstatus pendidikan tinggi akan berisiko mengalami kegemukan. Adanya edukasi tentang masalah nutrisi sangat dibutuhkan oleh masyarakat, oleh karena itu dalam Pengabdian kepada Masyarakat, diberikan juga edukasi nutrisi terutama pada jemaat yang mengalami kegemukan (overweight). Edukasi yang diberikan berupa informasi mengenai tingkat kecukupan energi, jumlah asupan lemak dan protein, memotivasi untuk

$$
\text { Kesehatan } 405
$$


mengkonsumsi sayur dan buah sesuai dengan tingkat kemampuan jemaat dalam membeli (faktor ekonomi).

Pentingnya edukasi kesehatan dapat menjadi salah satu cara untuk mencegah kegemukan, yaitu dengan adanya penambahan informasi diharapkan adanya perubahan perilaku, dan perubahan dalam melakukan aktivitas fisik. Promosi kesehatan juga perlu dilakukan dan ditingkatkan secara terus-menerus untuk mengurangi angka kejadian obesitas dan dampaknya terhadap status kesehatan.

Hal ini diperkuat dengan adanya penelitian yang dilakukan oleh Andria (2013) yang menyatakan bahwa "Ada hubungan yang bermakna antara perilaku olahraga dan stress dengan tingkat hipertensi pada lansia". Hal ini terkait dengan pola makan yang salah yaitu terlalu banyak makan makan dan minuman yang mengandung kadar gula darah seperti minuman dan makanan manis. Berdasarkan hasil data demografik terlihat usia produktif (15-59 tahun) masih lebih banyak dibandingkan untuk usia Lansia ( lebih dari 60 tahun). Hal ini tentunya menekankan pentingnya edukasi kesehatan untuk menjaga kesehatan sebagai "tabungan dimasa tua".

Sumber daya manusia adalah hal penting dalam membangun suatu bangsa dan kualitasnya sangat dipengaruhi oleh status kesehatan, gizi, lingkungan hidup dan tentunya kemampuan ekonomi keluarga. Jemaat Indonesia House of Praise (IHOP) sebagaian besar memiliki keadaan ekonomi kurang dengan status pendidikan rendah tentunya menjadi salah satu faktor risiko untuk dapat meningkatkan status kesehatannya. "Status kesehatan seseorang atau suatu komunitas masyarakat merupakan hasil interaksi berbagai faktor baik faktor internal maupun faktor eksternal" (Hapsari, Sari \& Pradono, 2019) . Faktor internal terdiri dari faktor fisik dan psikis, sedangkan faktor esternal terdiri berbagai faktor seperti sosial, budaya masyarakat, lingkungan fisik, politik, ekonomi, Pendidikan dan sebagainya. Selain itu Hapsari, Sari \& Pradono (2019) juga mengatakan bahwa status kesehatan dipengaruhi oleh empat faktor utama yaitu lingkungan, gaya hidup/perilaku, pelayanan kesehatan dan faktor genetik (keturunan).
Hasil pengukuran lainnya adalah hasil kadar koelsterol, asam urat dan gula darah. Pada bagian pemeriksaan ini tidak semua jemaat ikut diperiksa dikarenakan alat pemeriksaan yang terbatas pada saat itu dan tidak semua peserta diperiksa karena pemeriksaan lanjut dibutuhkan jika peserta memiliki faktor risiko. Pada pemeriksaan gula darah, kolesterol dan asam urat diprioritaskan pada kategori usia lanjut. Hal ini diperkuat dengan penelitian yang dilakukan oleh Waloya, Rimbawan \& Andarwulan (2013) pada pria dan wanita dewasa yang mengatakan bahwa tidak adanya pengaruh asupan protein terhadap kadar kolesterol darah, demikian pula halnya dengan asupan karbohidrat dan asupan kolesterol. Tingkat aktivitas fisik dan jenis kelamin berpengaruh nyata terhadap kadar kolesterol darah. Oleh karena itu pada pemeriksaan lanjutan seperti pemeriksaan kadar gula dalam darah, kolesterol dan asam urat diprioritaskan pada usia lanjut pada kegiatan Pengabdian kepada Masyarakat di IHOP Mangga Besar.

\section{KESIMPULAN DAN SARAN}

Bentuk evaluasi yang dilakukan adalah tanya jawab selama proses pengobatan dan pemeriksaan kesehatan berlangsung. Evaluasi diberikan dalam bentuk pertanyaan secara lisan yaitu manfaat yang didapatkan oleh peserta selama pemberian edukasi, deteksi dini dan pengobatan gratis.

Kegiatan Pengabdian kepada Masyarakat berjudul Deteksi dini dan edukasi kesehatan pada jemaat IHOP Mangga Besar Jakarta berjalan dengan lancar. Kerjasama antara tim PkM Fakultas Ilmu Keperawatan dan Kesehatan dengan pihak gereja IHOP Mangga Besar Jakarta juga terlaksana dengan baik. Setiap peserta yang hadir pada kegiatan pemeriksaan kesehatan dan pengobatan gratis juga merasa senang, antusias dan semakin memahami informasi tentang kesehatan. Pada akhir kegiatan pelaksanaan tim PkM baik dari gereja maupun tim dari UPH melakukan evaluasi secara keseluruhan yaitu keberhasilan selama proses berlangsung, partisipan/peserta yang hadir 
uku\%20Program\%20Indonesia\%20Sehat\%20denga n\%20Pendekatan\%20Keluarga.pdf

Kemenkes RI. (2017). Pedoman monitoring dan evaluasi pelaksanaan program Indonesia Sehat dengan pendekatan keluarga. Diakses dari http://www.depkes.go.id/resources/download/lain/

Kusumawati, D., Wiardani, N., \& Sugianti, P. (2014). Diet mencegah dan mengatasi gangguan asam urat. Jurnal Ilmu Gizi, Vol 5 (1): 69-78. Rerieved from http://www.poltekkesdenpasar.ac.id/wpcontent/uploads/2017/12/kusumayanti-JIG-Vol-5-

No-1-Feb-2014.pdf

Kusumawaty, J., Hidayat, N \& Ginanjar, E. (2016). Hubungan jenis kelamin dengan intensitas hipertensi padalansia di wilayah kerja Puskesmas Lakbok Kabupaten Ciamis. Mutiara Media. Vol 16 (2): 46-51

Rahajeng, E \& Tuminah, S. (2009). Prevalensi Hipertensi dan Determinannya di Indonesia. Majalah Kedokteran Indonesia, Vol 59 (12): 580587

Sulastri, D., Elmatris \& Ramadhani, R. (2012). Hubungan Obesitas dengan Kejadian Hipertensi pada masyarakat Etnik Minagkabau di Kota Padang. Majalah Kedokteran Andalas No.2. Vol.36. hal 188-201

Waloya, T., Rimbawan \& Andarwulan, N. (2013). Hubungan antara Konsumsi Pangan dan Aktivitas Fisik dengan Kadar Kolesterol Darah Pria dan Wanita Dewasa di Bogor. Jurnal Gizi dan Pangan, 8(1): 9-16. ISSN 1978 - 1059

WHO-ISH Hypertension Guideline Committee. (2013). Guidelines of the management of hypertension. Journal Hypertension.;21(11): 1983-

92. 